\title{
PENGARUH MODEL PEMBELAJARAN INKUIRI TERHADAP KETERAMPILAN GENERIK SAINS SISWA KELAS XI IPA SMA NEGERI 1 PANGKAJENE SIDRAP
}

\author{
Haryanti Putri Rizal \\ Muhammad Danial \\ FMIPA Universitas Negeri Makassar \\ E-mail: haryantiputrirz@gmail.com dan muh_niels@yahoo.com
}

\begin{abstract}
This research was a quasi experimental aimed to investigate the influenced of inquiry learning model to generic science skills of students class XI IPA SMAN 1 Pangkajene Sidrap on buffer solution subject matter. Research design used "Nonequivalent Control Group Design" that consist of two variable there are inquiry learning model as dependent variable and generic science skills as independent variable. Population in this research is students class XI IPA SMAN 1 Pangkajene Sidrap academic year 2012/2013 which amount 240 students. The sample choosen by class random sampling and have choosen XI IA 1 as experiment class consist of 34 students and XI IA 2 as control class consist of 35 students. Instrument that used is generic science skills test (KGS) were integrated into buffer solution subject matter that includes indirect observation, sense of scale, logical frame, causality, mathematical modeling and concept formation. The data was collected by given generic science skills test in pretest and posttest by objective test. Data were analyzed by descriptive statistics and inferential statistics. The descriptive results showed that generic science skills student of experiment class get $\mathrm{N}$-gain average 0.71 in high categories and control class get $\mathrm{N}$-gain average 0.31 in medium categories. The inferential statistics analysis showed that $t_{\text {calculated }} 7,17>t_{\text {table }} 1,68$ in significant level $\alpha=0.05$, so $H_{0}$ failed or $H_{1}$ accepted. The result of analysis describe that inquiry learning model have positive influenced to generic skills science of students on buffer solution subject matter.
\end{abstract}

Kata Kunci: Inquiry, Keterampilan Generik Sains

Pengembangan kemampuan siswa dalam bidang sains merupakan salah satu kunci keberhasilan dalam menyesuaikan diri dengan perubahan dan kesiapannya dalam memasuki dunia teknologi. Menghadapi perkembangan dunia yang semakin melaju saat ini, siswa perlu dibekali keterampilan sains dan kompetensi yang memadai selama menempuh pendidikan mulai dari pendidikan dasar hingga pendidikan tinggi. Oleh karena itu, peningkatan keterampilan dan mutu pendidikan sains di semua jenjang pendidikan harus selalu diupayakan.

Gallagher mengemukakan bahwa perkembangan dunia yang semakin melaju tersebut dapat dihadapi melalui paradigma baru pembelajaran sains, yaitu memberikan sejumlah pengalaman kepada siswa untuk mengerti dan membimbing mereka untuk menggunakan pengetahuan sains tersebut
(Liliasari, 2007).Hal ini berarti bahwa dalam mengembangkan kompetensi dan pemahaman sains siswa perlu diperhatikan keterampilan dasar siswa, selain harus memiliki kemampuan dalam pemahaman konsep, mereka juga harus mampu mengintegrasikan keterampilan dasar yang dimilikinya dengan pengetahuan sains untuk memenuhi kebutuhan hidup siswa di berbagai situasi hidupnya (Sunyono, 2009).

Kemampuan berpikir dan bertindak berdasarkan pengetahuan sains yang dimiliki melalui kerangka berpikir sains disebut keterampilan generik sains (Liliasari, 2005).Dengan adanya keterampilan ini siswa dapat mempelajari sains dengan baik.Brotosiswoyo (2001) menyatakan kemampuan generik sains penting dalam membangun kepribadian dan pola berpikir tingkat tinggi. Hal tersebut dikarenakan 
kemampuan generik sains sebagai dasar dalam proses berpikir tingkat tinggi yang meliputi kemampuan berpikir kreatif, kritis, pengambilan keputusan dan pemecahan masalah kehidupan sehari-hari (Costa, 1985).

Keterampilan generik sains (KGS) dikenal sebagai keterampilan inti, keterampilan essensial dan keterampilan dasar serta merupakan sesuatu yang dibutuhkan dalam pekerjaan (Mehralizah, 2008). Keterampilan generik sains membantu siswa untuk belajar dan menunjukkan bagaimana cara belajar yang baik.Belajar sains sarat akan kegiatan berpikir yang dikembangkan melalui 9 macam keterampilan generik sains (Brotosiswoyo, 2000) yang meliputi (1) pengamatan langsung (direct observation), (2) Pengamatan tak langsung (indirect observation), (3) kesadaran tentang skala besaran (sense of scale), (4) bahasa simbolik (symbolic language), (5) kerangka logika taat-asas (logical self- consistency) dari hukum alam, (6) inferensi logika, (7) hukum sebab-akibat (causality), (8) pemodelan matematis (matemathical modelling), dan (9) membangun konsep (concept formation). Selain kesembilan indikator tersebut, indikator keterampilan generik sains yang dapat dikembangkan dalam bidang kimia adalah (10) Abstraksi (Abstraction), dan (11) tilikan ruang (visual spatial) (Suyanti, 2006; Sudarmin, 2007).

Kimia sebagai salah satu bagian dari sains mempelajari tentang struktur, susunan, sifat, perubahan materi serta energi yang menyertainya (Depdiknas, 2004). Lingkup pembelajaran kimia tidak hanya terbatas pada penggunaan ataupun penurunan rumus saja, melainkan merupakan produk dari sekumpulan fakta, teori, prinsip dan hukum yang diperoleh dan dikembangkan berdasarkan serangkaian kegiatan (proses) yang mencari jawaban atas apa, mengapa dan bagaimana. Menurut Arnas (2012) secara garis besar kimia mencakup dua bagian, yakni kimia sebagai proses dan kimia sebagai produk. Kimia sebagai produk meliputi sekumpulan pengetahuan yang terdiri atas fakta, konsep dan prinsip ilmu kimia. Sedangkan kimia sebagai proses meliputi keterampilan-keterampilan dan sikap yang dimiliki oleh para ilmuwan untuk memperoleh dan mengembangkan produk kimia. Hal ini berarti bahwa dalam pembelajaran kimia di sekolah tidak cukup hanya memperhatikan aspek kognitif saja, tetapi aspek afektif (sikap ilmiah) dan psikomotorik (unjuk kerja) juga mutlak diperhatikan.agar dapat membantu siswa dalam menguasai konsep dan memperoleh sikap ilmiah serta kecakapan hidup.

Salah satu upaya yang dapat dilakukan untuk meningkatkan kualitas pembelajaran kimia adalah melalui pemilihan model pembelajaran inovatif yang dapat membantu siswa untuk mencapai tujuan pembelajaran. Salah satu model pembelajaran yang dapat membangun pengetahuan siswa, menarik minat siswa dengan memberikan sejumlah pemahaman kepada siswa untuk menguasai kimia dan membimbing mereka untuk menggunakan pengetahuan kimia tersebut adalah model pembelajaran inkuiri.

Model pembelajaran inkuiri merupakan model pembelajaran yang memberikan kesempatan kepada siswa untuk memiliki pengalaman belajar yang nyata dan aktif, siswa dilatih bagaimana memecahkan masalah sekaligus membuat keputusan. Tujuan dari penggunaan model pembelajaran inkuiri adalah mengembangkan kemampuan berpikir secara sistematis, logis dan kritis atau mengembangkan kemampuan intelektual sebagai bagian dari proses mental sehingga siswa tidak hanya dituntut menguasai materi pelajaran, tetapi bagaimana siswa dapat mengembangkan potensi yang dimilikinya (Sanjaya, 2009).

Pembelajaran inkuiri merupakan pembelajaran yang berpusat pada siswa karena siswa dilibatkan dalam proses memahami masalah, merancang hipotesis, mendesain eksperimen, mengamati, menganalisis data dan memberikan kesimpulan mengenai masalah atau fenomena. Kemampuan inkuiri dalam 
aktivitasnya dapat berperan dalam pengembangan konsep sains, keterampilan berpikir dan pengalaman.Melalui inkuiri, siswa dapat melakukan penyelidikan dalam penemuan konsep kimia dan pengembangannya, serta menjelaskan konsep dan data (Sanjaya, 2009).

Penelitian yang telah dilakukan sebelumnya menunjukkan bahwa pembelajaran inkuiri meningkatkan hasil belajar siswa, khususnya dalam aspek keterampilan pemecahan masalah, kemampuan menjelaskan data, berpikir kritis dan memahami konsep-konsep dalam pembelajaran sains (Chiappetta \& russel, 1982).Hamdu (2007) meneliti tentang penerapan model pembelajaran inkuiri, hasil penelitian menunjukkan bahwa penerapan model pembelajaran inkuiri dapat meningkatkan pemahaman konsep siswa secara umum serta mengembangkan kemampuan dasar bekerja ilmiah dan sikap ilmiah siswa.Ia juga menyatakan bahwa secara umum siswa dan guru memberikan tanggapan yang positif terhadap pembelajaran model inkuiri tersebut.

Melalui penerapan model pembelajaran inkuiri dalam pembelajaran akan menciptakan suasana belajar yang lebih bermakna bagi siswa, memotivasi siswa untuk lebih kreatif dalam memecahkan masalah yang mungkin ditemukan dan lebih tertarik untuk mempelajari sains, sehingga pada akhirnya aktivitas belajar lebih meningkat dan siswa memperoleh kecakapan-kecakapan berpikir dan bertindak secara ilmiah (Sanjaya, 2009).

Pokok bahasan yang dipilih dalam penelitian ini adalah larutan penyangga yang diajarkan di kelas XI IPA yang memuat berbagai konsep dan rumus yang menuntut pemahaman, keterampilan siswa dalam berhitung dan menghubungkan antar konsep yang telah dimiliki dan konsep yang baru diajarkan. Selain itu, materi ini memiliki karakteristik yang bersifat abstrak (reaksi asam basa), bersifat pemahaman konsep (sifat larutan penyangga), bersifat riil dan aplikatif (peranan larutan penyangga). Sehingga membutuhkan pengajaran nyata yang dapat memberikan pengalaman belajar kepada siswa agar konsep yang abstrak tersebut dapat dibuktikan sehingga siswa tidak kesulitan dalammemahami konsep serta memperoleh bekal keterampilan yang memadai .

Indikator keterampilan generik sains yang akan dikembangkan disesuaikan dengan model pembelajaran inkuiri dan konten materi larutan penyangga yang akan diajarkan, indikator tersebut mencakup pengamatan tidak langsung, kesadaran tentang skala, kerangka logika taat azas, sebab-akibat, pemodelan matematika, dan membangun konsep.

Berdasarkan uraian mengenai keterampilan generik sains, pembelajaran kimia dan model pembelajaran inkuiri tersebut, tujuan penelitian ini adalah untuk mengetahui pengaruh model pembelajaran inkuiri terhadap keterampilan generik sains siswa pada materi pokok larutan penyangga.

\section{METODE}

Metode yang digunakan adalah eksperimen semu (Sugiyono, 2010) yang terdiri dari dua kelas. Kelas eksperimen menggunakan model pembelajaran inkuiri sedangkan kelas kontrol dengan pembelajaran konvensional.

Populasi penelitian ini adalah seluruh siswa kelas XI IPA SMA Negeri 1 Pangkajene Sidrap (pangsid) dan pengambilan sampel menggunakan class random sampling diasumsikan bahwa populasi bersifat homogen. Prosedur penelitian terdiri dari beberapa tahapan, yaitu: (1) tahap pendahuluan, pada tahap ini dilakukan observasi awal, mengidentifikasi masalah penelitian dan studi kepustakaan serta menyusun instrumen penelitian, (2) tahap persiapan, dilakukan dengan berkonsultasi dengan guru bidang studi kimia kelas XI IPA SMA Negeri 1 Pangsid mengenai keadaan siswa, materi dan rencana pembelajaran, serta menyusun RPP dan surat 
izin penelitian, (3) tahap pelaksanaan, pada tahap ini dilakukan pretest, kegiatan pembelajaran dan posttest, analisis data.

Analisis data dalam penelitian ini dianalisis menggunakan teknik analisis statistik deskriptif untuk menyajikan atau mengungkapkan tingkat keterampilan generik sains siswa pada materi pokok larutan penyangga. Peningkatan keterampilan generik sains sebelum dan setelah kegiatan pembelajaran dihitung dengan rumus g factor (gain score normalized) sebagai berikut:

$$
<\mathrm{g}>=\frac{\text { S post }- \text { Spre }}{\text { S maks }- \text { S pre }}
$$

Dengan :

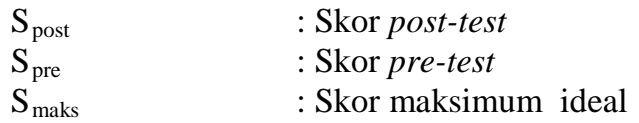

Kategorisasi nilai N-gain disajikan pada tabel 1.

Tabel 1. Kategori Nilai N-gain

\begin{tabular}{|c|c|}
\hline Nilai N gain & Kategori \\
\hline $\mathrm{g}>0.7$ & Tinggi \\
\hline $0.3 \leq \mathrm{g} \leq 0.7$ & Sedang \\
\hline $\mathrm{g}<0,3$ & Rendah \\
\hline
\end{tabular}

Analisis statistik inferensial digunakan untuk menguji hipotesis, yang terlebih dahulu harus dilakukan beberapa uji prasyarat. Uji prasyarat yang dilakukan adalah uji normalitas untuk mengetahui data yang diperoleh berasal dari populasi yang terdistribusi normaldan uji homogenitas untuk mengetahui apakah data yang diperoleh berasal dari populasi yang bersifat homogen, untuk menguji hipotesis adanya pengaruh model pembelajaran inkuiri terhadap keterampilan generik sains siswa kelas XI IPA SMA Negeri 1 Pangkajene Sidrap dilakukan uji t.

\section{HASIL}

Hasil analisis statistik deskriptif tingkat keterampilan generik sains siswa sebelum dan setelah diberi perlakuan untuk masing-masing kelas disajikan pada tabel 2 .

Tabel 2. Tabel Statistik Deskriptif Prestest dan Posttest Kelas Eksperimen dan Kontrol

\begin{tabular}{|c|c|c|c|c|}
\hline \multirow{2}{*}{$\begin{array}{c}\text { Statistik } \\
\text { Deskriptif }\end{array}$} & \multicolumn{2}{|c|}{$\begin{array}{c}\text { Kelas } \\
\text { Eksperimen }\end{array}$} & \multicolumn{2}{c|}{$\begin{array}{c}\text { Kelas } \\
\text { Kontrol }\end{array}$} \\
\cline { 2 - 5 } & $\begin{array}{c}\text { Pre- } \\
\text { test }\end{array}$ & $\begin{array}{c}\text { Post- } \\
\text { test }\end{array}$ & $\begin{array}{c}\text { Pre- } \\
\text { test }\end{array}$ & $\begin{array}{c}\text { Post- } \\
\text { test }\end{array}$ \\
\hline Nilai tertinggi & 44 & 96 & 40 & 72 \\
\hline Nilai terendah & 16 & 60 & 16 & 36 \\
\hline Rata-rata & 32.7 & 78.2 & 30.41 & 61.98 \\
\hline Median & 32 & 80 & 28 & 68 \\
\hline Rentang & 28 & 36 & 24 & 36 \\
\hline Varians & 62.63 & 85.12 & 40.55 & 91.85 \\
\hline Standar deviasi & 7.91 & 9.22 & 6.36 & 9.58 \\
\hline Jumlah siswa & 34 & 34 & 35 & 35 \\
\hline
\end{tabular}

Adapun nilai N-gain keterampilan generik sains pada masing-masing kelas berdasarkan indikator keterampilan generik sains disajikan pada table 3 .

Tabel 3. Nilai N-gain Keterampilan Generik Sains untuk tiap Indikator.

\begin{tabular}{|c|c|c|c|c|c|}
\hline \multirow{2}{*}{ No } & \multirow{2}{*}{$\begin{array}{l}\text { Indikator } \\
\text { KGS }\end{array}$} & \multicolumn{2}{|c|}{$\begin{array}{c}\text { Kelas } \\
\text { Eksperimen }\end{array}$} & \multicolumn{2}{|c|}{ Kelas Kontrol } \\
\hline & & $\begin{array}{c}\mathrm{N}- \\
\text { gain }\end{array}$ & Kategori & $\begin{array}{l}\mathrm{N}- \\
\text { gain }\end{array}$ & Kategori \\
\hline 1. & $\begin{array}{l}\text { Pengamatan } \\
\text { tidak } \\
\text { langsung }\end{array}$ & 1.00 & Tinggi & 0.86 & Tinggi \\
\hline 2. & $\begin{array}{l}\text { Kesadaran } \\
\text { tentang } \\
\text { skala }\end{array}$ & 0.86 & Tinggi & 0.78 & Tinggi \\
\hline 3. & $\begin{array}{l}\text { Kerangka } \\
\text { logika taat } \\
\text { azas }\end{array}$ & 0.6 & Sedang & 0.38 & Sedang \\
\hline 4. & $\begin{array}{l}\text { Hukum } \\
\text { Sebab - } \\
\text { akibat }\end{array}$ & 0.28 & Rendah & 0.61 & Sedang \\
\hline 5. & $\begin{array}{l}\text { Pemodelan } \\
\text { matematika }\end{array}$ & 0.78 & Tinggi & 0.86 & Tinggi \\
\hline \multirow[t]{2}{*}{6.} & $\begin{array}{l}\text { Membangun } \\
\text { konsep }\end{array}$ & 0.71 & Tinggi & 0.32 & Rendah \\
\hline & Rata-rata & 0.71 & Tinggi & 0.53 & Sedang \\
\hline
\end{tabular}

\section{PEMBAHASAN}

Hasil analisis normalitas dan homogenitas data diperoleh bahwa data berdistribusi normal dan berasal dari populasi yang homogen. Selanjutnya, pengujian hipotesis dalam penelitian ini menggunakan uji-t dan diperoleh nilai $\mathrm{t}$ hitung $=7,17$; dan nilai $\mathrm{t}$ daftar distribusi $\mathrm{t}$ pada taraf signifikansi $\alpha=0,05$ dengan $\mathrm{dk}=67$ diperoleh $\mathrm{t}_{\text {tabel }}=1,68$ (melalui interpolasi) 
sehingga diperoleh $t_{\text {hitung }}=7.17>t_{\text {tabel }}=$ 1.68. dengan demikian $\mathrm{H}_{0}$ ditolak atau $\mathrm{H}_{1}$ diterima. Hal ini berarti bahwa ada pengaruh positif model pembelajaran inkuiri terhadap keterampilan generik sains sains siswa kelas XI IPA SMA Negeri 1 Pangkajene Sidrap pada materi larutan penyangga.

Berdasarkan data pada tabel 3 menunjukkan bahwa dari enam indikator KGS yang diteliti, ada empat indikator yang menunjukkan pencapaian lebih tinggi pada kelas eksperimen dibandingkan kelas kontrol yakni pengamatan tak langsung, kesadaran tentang skala, kerangka logika, dan membangun konsep. Sedangkan dua indikator terakhir yakni hukum sebab akibat dan permodelan matematika menunjukkan pencapaian yang lebih tinggi dari kelas kontrol dari pada kelas eksperimen. Namun secara rata-rata, nilai gain skor KGS dari eksperimen lebih baik daripada nilai gain skor kelas kontrol. Hal ini dapat disebabkan tingkat partisipasi atau aktivitas siswa dalam menemukan konsep pada kelas eksprimen (kelas yang dibelajarkan dengan model inkuiri) lebih maksimal. Hal ini juga tidak terlepas dari filosofi model inkuiri yang menyatakan bahwa model pembelajaran inkuiri merupakan model pembelajaran yang menekankan pada aktivitas siswa secara maksimal untuk mencari dan menemukan, artinya model inkuiri menempatkan siswa sebagai subjek belajar.

Secara umum hasil perhitungan gain skor dengan penerapan model inkuiri dibandingkan dengan gain skor penerapan model konvensional sebagaimana disajikan pada tabel 3 menunjukkan nilai rata-rata gain skor lebih baik pada model pembelajaran inkuiri sebesar 0,71 dan termasuk kategori tinggi sedangkan untuk model konvensional hanya sebesar 0,53 dan termasuk kategori sedang. Begitupun hasil skor rata-rata dan nilai tertinggi diperoleh dari kelas eksperimen yang menerapkan model pembelajaran inkuiri sebagaimana ditunjukkan pada tabel 2.
Hal ini didukung oleh penelitian sebelumnya yang dilakukan oleh Iriany (2009) mengenai penerapan model pembelajaran inkuiri berbasis Teknologi Informasi pada materi laju reaksi. Berdasarkan hasil penelitiannya keterampilan generik sains dan keterampilan berpikir kreatif siswa meningkat dengan kategori tinggi. Demikian pula penelitian yang dilakukan oleh Samadin (2012) yang menerapkan pembelajaran inkuiri dengan model silver pada materi sifat koligatif larutan; hasil penelitiannya menyimpulkan bahwa keterampilan generik sains siswa meningkat secara umum dengan nilai tertinggi pada indikator keterampilan generik sains bahasa simbolik.

Penerapan model pembelajaran inkuiri dalam pembelajaran akan menciptakan suasana belajar yang lebih bermakna bagi siswa, memotivasi siswa untuk lebih kreatif dalam memecahkan masalah yang mungkin ditemukan dan lebih tertarik untuk mempelajari sains karena siswa diberikan pengalaman belajar yang nyata dan aktif, sehingga memperoleh keterampilan berpikir dan bertindak secara ilmiah atau keterampilan generik sains yang mencakup pengamatan langsung, pengamatan tidak langsung, kesadaran tentang skala, bahasa simbolik, kerangka logika taat azas, inferensi logika, hukum sebab-akibat, pemodelan matematika, membangun konsep, abstraksi dan tilikan ruang yang pada akhirnya penerapan keterampilan tersebut dalam pembelajaran akan menunjang aktivitas dan hasil belajar siswa.

Model pembelajaran inkuiri memusatkan pembelajaran pada siswa dan menempatkan guru hanya sebagai fasilitator, sehingga siswa akan terlibat lebih aktif dalam pembelajaran. Pembelajaran yang hanya membuat siswa pasif tentu tidak memotivasi dan membuat siswa untuk terus belajar, seperti halnya pada pembelajaran konvensional seperti yang selama ini dengan mudah dapat ditemui di sekolah-sekolah. Melalui hasil penelitian ini, setidaknya dapat 
menjadi preferensi guru kimia untuk memilih model pembelajaran yang sesuai, khususnya materi pokok larutan penyangga.

\section{KESIMPULAN DAN SARAN Kesimpulan}

Berdasarkan hasil analisis data dan pembahasan dapat disimpulkan bahwa model pembelajaran inkuiri berpengaruh positif terhadap keterampilan generik sains siswa kelas XI IPA SMAN 1 Pangkajene Sidrap pada materi pokok Larutan Penyangga.

\section{Saran}

Berdasarkan hasil penelitian dan pembahasan yang telah diuraikan, maka penulis menyarankan beberapa hal, antara lain :

1. Perlu dilaksanakan penelitian yang mengkaji secara holistik dari sebelas indikator keterampilan generik sains, tidak hanya enam indikator saja seperti pada penelitian ini agar dapat mengukur seluruh keterampilan generik sains yang dimiliki siswa.

2. Hendaknya guru kimia dalam mengajarkan konsep materi larutan penyangga lebih banyak memberikan latihan-latihan lebih intensif, memberikan penjelasan, dan penekanan pada bagian sub konsep yang kurang dikuasai atau dianggap sulit oleh siswa, sehingga siswa tidak mengalami kesulitan dalam mengerjakan soal-soal dan mempelajari materi larutan penyangga.

3. Hendaknya guru lebih variatif dalam menerapkan model pembelajaran agar siswa lebih termotivasi, aktif, dan kreatif dalam mempelajari kimia.

\section{DAFTAR RUJUKAN}

Arnas, Erwina. 2012. Pengaruh Penggunaan Laboratorium Virtual dan Laboratorium Real Terhadap Sikap Ilmiah dan Hasil Belajar Kimia Siswa SMA Pada Pokok Bahasan Larutan Penyangga. Medan : Program Pasca Sarjana UNIMED
Badan Standar Nasional Pendidikan. 2006. Standar Isi untuk Satuan Pendidikan Dasar dan Menengah. Jakarta: Depdiknas

Brotosiswoyo. B.S (2000) Kiat Pembelajaran MIPA dan Kiat Pembelajaran Fisika di Perguruan Tinggi. Jakarta : Departemen Pendidikan Nasional.

Brotosiswoyo. B.S. (2001). Hakekat Pembelajaran MIPA dan Kiat pembelajaran Kimia di Perguruan Tinggi. Jakarta : PAU-PPAI

Chiappetta, EL \& Ruseel, J.M. 1982. The Relationship Among Logical Thinking, Problem Solving Instruction, Knowledge and Applicaton of Earth Science Subject Matter. Science Education.

Costa A.L, and Pressceincen, B.Z. 1985. Glossary of Thinking Skills, in A.L Costa (ed), Developing Minds: A Resource Book for Teaching Thinking, Alexandria: ASCD, 303-312

Dahar, R.W. 1978. Teori-Teori Belajar dan Pembelajaran. Jakarta: Erlangga.

Darliana. 2006. Kompetensi Generik IPA. (online), tersedia: p4tkipa.org[2 Januari 2013]

Depdiknas. 2005. Standar Nasional Pendidikan. Jakarta: Depdiknas

Gallagher. 2007. Teaching Science for Understanding a Practical Guide for Middle and High School Teachers.New Jersey: Pearson Merrill Hall.

Hamdu. 2007. Pembelajaran Hidrolisis Garam Dengan Model Inkuiri untuk Mengembangkan Kemampuan Dasar Bekerja Ilmiah Siswa Kelas XI. Bandung: Sekolah Pasca Sarjana UPI.

Harnanto. 2009. Kimia untuk Kelas XI. Jakarta: Pusat Perbukuan Departemen Pendidikan Nasional.

Hartono. 2006. Pembelajaran Fisika Modern Bagi Mahasiswa Calon Guru. Bandung: SPS UPI.

Hager, P., Holland, S \& Beckett, D. 2002. Enhancing the Learning and 
Employability of Graduates: The Role of Generic Skills. Melbourne:B-HERT.

Iriany. 2009. Model Pembelajaran Inkuiri Laboratorium Berbasis Teknologi Informasi Pada Konsep Laju Reaksi untuk Meningkatkan Keterampilan Generik Sains dan Berpikir Kreatif Siswa SMA. Bandung: Sekolah Pasca Sarjana UPI.

Joyce, Bruce \& Weill, Marsha.1980. Model of Teaching. New Jersey: Prentice-Hall.

Joyce, Bruce \& Weill, Marsha. 2000. Model of Teaching Sixth Edition. New Jersey: Prentice-Hall

Liliasari. 2005. Membangun Keterampilan Berpikir Kritis Indonesia Melalui Pendidikan Sains. Bandung: UPI

Liliasari. 2008. Peningkatan Kualitas Pendidikan Kimia dari Pemahaman Konsep Kimia Menjadi Berpikir Kimia. Bandung: Sekolah Pasca Sarjana UPI.

Liliasari. 2010. Pengembangan Keterampilan Berpikir melalui Pembelajaran Sains Menuju Masa Depan. Dalam Teori, Paradigma, Prinsip dan Pendekatan Pembelajaran MIPA dalam Konteks Indonesia. FMIPA UPI.

McBride, J.W, Bhatti, M.I. 2004. Using An Inquiry Approach to Teach Science to Secondary School Science Teacher. 10 P Journal Volume (Issue) 39 (5): 1-6

Mehralizah. 2008. Pusat Sumber Belajar Dit. (online), tersedia: psma.Langgeng.Psb.Psma.org. [ [ 2 Januari 2013]

Meltzer, D.E. 2002. The Relationship Between Mathematics Preparation and Conceptual Learning Gain in Physics Hidden Variable in Diagnostics Pretest Scores. American Journal of Physics. 70 (12). 1259-1267.

Muhibbin, Syah. 2006. Psikologi Pendidikan dengan Pendekatan Baru. Bandung: PT. Remaja Rosdakarya.

Mulyasa, E. 2009. Praktik Penelitian Tindakan Kelas. Bandung: PT. Remaja Rosdakarya.
Nasional Research Council. 1996. National Science Education Standards. Washington DC: National Academic Press.

Purba, M. 2006. Kimia Untuk SMA Kelas XI. Jakarta: Erlangga.

Ramlawati, Assesmen Portofolio Elektronik Dalam Meningkatkan Keterampilan Generik Sains Mahasiswa Pada Praktikum Kimia Anorganik. Bandung : Universitas Pendidikan Indonesia.

Rutherford, J and A. Ahlgren. 1989. Science for All Americans. New York: Oxford University Press.

Sagala. 2004. Konsep dan Makna Pembelajaran. Bandung. Alfabeta.

Samadin. 2012. Penerapan Pembelajaran Inkuiri Model Silver untuk Mengembangkan Keterampilan Generik Sains Siswa Pada Konsep Sifat Koligatif Larutan. Bandung: UIN Sunan Gunung Jati.

Sanjaya,W. 2009. Strategi Pembelajaran Berorientasi Standar Proses Pendidikan. Jakarta: Kencana Prenada Media Group.

Subana, M. 2000. Statistik Pendidikan. Pustaka Setia. Bandung.

Sudarmin. 2007. Pengembangan Model Pembelajaran Kimia Organik dan Keterampilan Generik Sains Bagi Calon Guru Kimia. Disertasi. Bandung: Sekolah Pasca Sarjana UPI.

Sugiyono. 2010.Metode Penelitian Pendidikan, Bandung: Alfabeta.

Suharsini. 2007. Kimia dan Kecakapan Hidup. Bandung: Ganeca Exact.

Sunyono. 2009. Pembelajaran IPA dengan Keterampilan Generik Sains. Tersedia: blog.unila.ac.id/sunyono/files/2009/06/k eterampilan-generik.pdf [19 April 2013]

Suyanti, R.D. (2006). Pembekalan Kemampuan Generik bagi Calon Guru Melalui Pembelajaran Kimia Anorganik Berbasis Multimedia Komputer. Disertasi Doktor Ilmu Pendidikan. Bandung:SPs UPI.

Syam. 2007.Praktikum Inkuiri. Bandung: SPs UPI. 
Trianto. 2007. Model-Model Pembelajaran Inovatif Berorientasi Konstruktivistik: Konsep, Landasan Teoritis Praktis dan Implementasinya. Surabaya: Prestasi Pustaka Publisher.

Trowbridge, L.W. et al. 1973. Teaching Science by Inquiry in The Secondary School Second Edition. Ohio: Charles E. Merrill Publishing Company, A. bell Howell Company. 